\title{
VIETNAMESE NON-ENGLISH MAJORED EFL UNIVERSITY STUDENTS' RECEPTIVE KNOWLEDGE OF THE MOST FREQUENT ENGLISH WORDS
}

\author{
Dang Thi Ngoc Yen* \\ School of Education, University of Leeds \\ Hillary Place, Woodhouse Lane, Leeds, U.K \\ Received 23 February 2020 \\ Revised 20 May 2020; Accepted 27 May 2020
}

\begin{abstract}
The receptive knowledge of 442 non-English majored university students in a General English program in Vietnam was measured with Webb, Sasao, and Ballance's (2017) New Vocabulary Levels Test. It was found that despite 10 years of formal English language instruction, nearly half of the participants had not mastered the most frequent 1,000 words and more than $90 \%$ had not mastered the most frequent 2,000 words. The study calls for more attention to high-frequency words in English language instruction in Vietnamese EFL context.
\end{abstract}

Keywords: Vietnamese EFL learners; vocabulary knowledge; high frequency words; testing

\section{Introduction}

Vocabulary knowledge has a significant contribution to English as a Foreign Language (EFL) learners' development of language skills as well as their overall language proficiency (Qian \& Lin, 2020). Therefore, it is important for English language teachers to help learners achieve a solid knowledge of English words. Vocabulary researchers (e.g., Nation, 2013; Schmitt, 2000) have suggested that EFL learners should learn words that occur frequently in the target language before words at lower frequency levels because words in the former group are smaller in number but may allow EFL learners to understand a much larger amount of text in various kinds of discourse. One question that arises is to what extent Vietnamese EFL learners know the most frequent words of English. Several studies have been conducted to address this question, but they focused on high school students (Nguyen, 2020; Vu \&

Tel.: +44 (0)1133433569

Email: T.N.Y.Dang@leeds.ac.uk
Nguyen, 2019), English majored university students (Nguyen \& Nation, 2011; Nguyen \& Webb, 2017), and English for Academic Purposes (EAP) students (Dang, 2020a). To the best of my knowledge, no studies have measured knowledge of Vietnamese nonEnglish majored university students who learn English for General Purposes although these students make up a large proportion of Vietnamese EFL learners. The present study was conducted to address this gap.

\section{Which words should EFL learners know?}

One question that many EFL teachers and learners wonder is how many words students need to know. A common assumption is that learners should learn all the words that are new to them. This is not a sensible decision. According to Oxford English Dictionary, there are about 600,000 words in English if each distinct sense is counted. Research also found that an average, educated, adult native speakers may know from 17,000-20,000 word families (Webb \& Nation, 2017). A word family includes a base form (e.g., inject), its 
inflections (injects, injected, injecting), and derivations (injector, injection). Learning all the words existing in English or all the words known by native speakers of that language is a daunting task to most EFL learners given that they only learn about 400 word families per year (Webb \& Chang, 2012). Therefore, vocabulary researchers (Nation, 2013; Schmitt, 2000) have suggested that a more useful and practical approach towards setting vocabulary learning goal is to target the words that learners need to know to complete certain tasks such as engaging in general conversations, watching television programs and movies, reading newspapers and academic texts, or listening to songs, academic lectures, and seminars. Corpus-based vocabulary studies analyzing vocabulary in corpora of different discourse types have indicated that EFL learners need to know from 3,000-9,000 word families to deal with these types of discourse (e.g., Dang \& Webb, 2014; Nation, 2006; Tegg, 2017; Webb \& Rodgers, 2009).

Given that learners should target the most frequent 9,000-word families, another question that emerges is which words should be learned first. Although different factors may affect the selection of words for learning, frequency is a key factor (Nation, 2013; Schmitt, 2000; Webb \& Nation, 2017). This suggestion is supported by evidence from corpus-based analyses. Dang and Webb (2020) analyzed the occurrences of words in 18 corpora which represented different kinds of spoken and written discourse and varieties of English. They found that the most frequent 1,000 words (e.g., great, know) accounted for $65 \%-88 \%$ of the words in these corpora. In contrast, the most frequent $1,001^{\text {st }}$ to $2,000^{\text {th }}$ words (e.g., combine, modern) and the most frequent $2,001^{\text {st }}$ to $3,000^{\text {th }}$ words (e.g., adolescent, comprehensive) made up $2 \%-10 \%$ and $1 \%-8 \%$ of the words in these corpora, respectively. Words at lower 1,000word frequency levels only covered no more than $1 \%$. It means that if learners have time to learn 1,000 words, learning the 1,000 words at a higher frequency level would allow them to know a larger proportion of words than learning the 1,000 words at a lower frequency level. As the proportion of known words in a text is closely related to comprehension (Laufer \& Ravenhorst-Kalovski, 2010; Schmitt, Jiang, \& Grabe, 2011; van Zeeland \& Schmitt, 2013), learning words according to frequency would help learners to improve their comprehension significantly.

Based on frequency, words can be classified into high, mid, and low-frequency words (Nation, 2013; Schmitt \& Schmitt, 2014). High-frequency words are those from the $1^{\text {st }}, 2^{\text {nd }}$ and $3^{\text {rd }} 1,000$-word levels. Midfrequency words are those from the $4^{\text {th }}$ to the $9^{\text {th }} 1,000$-word levels. Low-frequency words are those outside the most frequent 9,000 words. As high-frequency words accounted for most of the words in the texts, learning high-frequency words before mid and lowfrequency words means that learners would need to learn a smaller number of words but may be able to know a larger proportion of words in a text, which can enhance their comprehension significantly. This would then create a firm foundation for further vocabulary development. For these reasons, highfrequency words have been widely accepted as the starting point for vocabulary learning.

Although teachers can rely on their intuition to select high-frequency words, human intuition varies (Alderson, 2007). Fortunately, by counting the occurrences of words in a range of texts which represent natural language use, corpus linguistics offers a reliable way to create lists of highfrequency words (Dang, 2020b). As a result, a number of high-frequency word lists have been created with the aim to represent highfrequency vocabulary: West's (1953) General Service List, Nation's (2006) list of the most frequent 2,000 words in the British National Corpus (BNC2000), Brezina and Gablasova's (2015) New General Service List, and Nation's (2012) most frequent 2,000 words in the British Nation corpus and the Corpus 
of Contemporary American English (BNC/ COCA2000). Given the number of available high-frequency word lists, subsequent studies (Dang \& Webb, 2016a; Dang, Webb, \& Coxhead, 2020) have been conducted using information from corpora, teachers, and learners to determine which list is the most relevant to EFL learners. In terms of the information from corpora, they compared the percentage of words covered by items from the four-word lists in 9 spoken corpora and 9 written corpora which represent various kinds of spoken and written discourse and varieties of English. In terms of the information from teachers, they examined the perceptions of 78 experienced English language teachers about the usefulness of the items in these lists for their learners. This involved the participations of $25 \mathrm{EFL} / \mathrm{ESL}$ teachers who were native speakers of English, 26 Vietnamese EFL teachers, and 27 EFL teachers from varying countries. In terms of the information from learners, they measured knowledge of 135 Vietnamese EFL university students. The results consistently suggested that Nation's (2012) BNC/COCA2000 is the most suitable high-frequency word list for EFL learners in general and Vietnamese EFL learners in particular.

\section{EFL learners' knowledge of high- frequency words}

Knowing a word means knowing its forms (spoken forms, written forms, word parts), meanings (forms and meaning, concept and referents, associations), and uses (grammatical functions, collocations, constraints on use) (Nation, 2013). Among these aspects, the form and meaning relationship is the most basic and important aspect of vocabulary knowledge because it provides the foundation for further learning of other aspects (Webb \& Chang, 2012). For this reasons, previous research on EFL learners' vocabulary knowledge usually measured learners' knowledge of form and meaning relationship. Research with EFL learners in Denmark (Henriksen \& Danelund, 2015; Stæhr, 2008), Spain (Olmos, 2009), Indonesia (Nurweni \& Read, 1999), Taiwan (Webb \& Chang, 2012), and China (Sun \& Dang, 2020) has consistently shown that the majority of these learners have insufficient knowledge of the most frequent 2,000 words after a long period of formal English instruction.

Within the Vietnamese EFL context, Nguyen and Nation (2011) used the bilingual version of Nation and Belgar's (2007) Vocabulary Size Test to measure the vocabulary knowledge of 62 Vietnamese third year English majored students and found that these participants knew 6,000-7,000 words. While Nguyen and Nation (2011) provided a useful insight into the vocabulary knowledge of Vietnamese EFL learners, they used the Vocabulary Size Test to measure these learners' vocabulary knowledge. This test was originally designed to estimate the total number of words that test takers know and does not provide a precise picture of their knowledge of each 1,000-word frequency level (Nguyen $\&$ Webb, 2017). That is, although Nguyen and Nation's (2011) participants knew 6,000-7000 word families, it does not mean that they have mastered the most frequent 6,000-7,000 word families. For this reason, subsequent research on vocabulary knowledge of Vietnamese EFL learners has used tests that were specifically designed to measure vocabulary levels.

Two studies have been conducted to examine the vocabulary knowledge of high school students. Vu and Nguyen (2019) used Schmitt, Schmitt, and Clapham's (2001) Vocabulary Levels Test to measure the vocabulary knowledge of 500 Grade 12 high-school students. They reported a very small percentage of participants who had mastered the test levels: 14\% (2,000 word level), 4.4\% (3,000 word level), 4.6\% (academic vocabulary), 0.8\% (5000 word level) and $0.4 \%$ (10,000 word level). The Vocabulary Levels Test scores provide us with the information about the participants' 
knowledge of important vocabulary levels. However, they do not provide a precise picture of their knowledge of each 1,000-word level. Moreover, West's (1953) General Service List was used to represent high-frequency words in the Vocabulary Levels Test. The General Service List is dated and does not represent current vocabulary as well as Nation's (2012) BNC/COCA2000 (Dang \& Webb, 2016a; Dang, Webb, \& Coxhead, 2020).

In recognition of the limitation of the Vocabulary Levels Test, Nguyen (2020) used Webb, Sasao, and Ballance's (2017) Updated Vocabulary Levels Test tomeasure the vocabulary knowledge of 422 high school students. Unlike Schmitt et al.'s (2001) Vocabulary Levels Test, Webb et al.'s (2017) Updated Vocabulary Levels Test has five levels, each of which measures knowledge of the $1^{\text {st }}, 2^{\text {nd }}, 3^{\text {rd }}, 4^{\text {th }}$, and $5^{\text {th }} 1,000$ most frequent words of English. Also, items in the Updated Vocabulary Levels Test were selected from Nation's (2012) BNC/COCA lists. Nguyen (2020) found that as a whole, the participants had mastered the 1,000 and 2,000word levels, but had not mastered the 3,000, 4,000 and 5,000-word levels. Unfortunately, Nguyen did not report the results of individual students. Consequently, it is unclear from his study how many students had mastered each 1,000-word level of the Updated Vocabulary Levels Test. That is, although the participants as a whole had demonstrated mastery of the 1,000 and 2,000-word levels, there might be chances that a proportion of participants had not mastered these levels.

Two studies have been conducted to examine the vocabulary levels of university students. Both of them used Webb et al.'s (2017) Updated Vocabulary Levels Test and their findings are in line with $\mathrm{Vu}$ and Nguyen's (2019) findings. Nguyen and Webb's (2017) study with 100 first year English majored students showed that as a whole these students had mastered only the most frequent 1,000 words and had yet to master the 2,000 and 3,000 words. Similarly, Dang's (2020a) study with 66 first year EAP students revealed that only less than $20 \%$ of these participants had mastered the most frequent 2,000 words. The remaining participants either had mastered the most frequent 1,000 words (nearly 60\%) or had yet to master the most frequent 1,000 words (more than 20\%). It is important to note that Nguyen and Webb's (2017) participants were English majored students and Dang's (2020a) participants were EAP students. In Vietnamese EFL context, English-majored students and EAP students tend to study English more intensively and have higher language proficiency than non-English majored students. As most Vietnamese EFL university students are non-English majored students who learn English for General Purposes, measuring the vocabulary knowledge of this group of learners would provide further insights into the vocabulary level of Vietnamese EFL learners.

\section{The present study and research question}

Expanding on previous studies (Dang, 2020a; Nguyen \& Webb, 2017), the present study used Webb et al. (2017) Updated Vocabulary Levels Test to measure the vocabulary knowledge of non-English EFL learners in a General English program at a university in the north of Vietnam. Similar to non-English majored students at many universities in Vietnam, these students learned General English as a compulsory course in their first year at university. The research question that the study aims to address is:

To what extent do Vietnamese nonEnglish majored EFL students know words at the 1000, 2000, 3000, 4000, and 5000word frequency levels?

This study would provide a precise picture of Vietnamese non-English majored EFL students' knowledge of the most frequent 5,000 words of English as well as further insights into the effectiveness of the English language programs in Vietnam on vocabulary development. 


\section{Methodology}

\subsection{Participants}

The participants were 442 Vietnamese EFL first year non-English majored students at a university in Hanoi, Vietnam. The participants shared features of non-English majored students in many universities in Vietnam. They had studied English for 10 years. Their ages ranged from 17 to 19 years old. At the time of the data collection, they were in the first semester of their first year at university. Based on their scores on the university's placement English tests, the students' general level of proficiency was estimated to be pre-intermediate, which corresponds to the A2 level of the Common European Framework of Reference for Languages.

\subsection{Instrument}

Webb et al.'s (2017) Updated Vocabulary Levels Test was conducted to measure the receptive vocabulary levels of the learners in the present study. The test was in the form of word-definition matching (see Figure 1). It has five levels: 1,000, 2,000, 3,000, 4,000, and 5,000 word levels. Each test level has 10 sections. Each section has six words together with three definitions. Test-takers have to choose three out of the six words to match with the three definitions. To master a level, test takers need to get 29 out of 30 correct answers.

\begin{tabular}{|l|l|l|l|l|l|l|}
\hline & average & discipline & knowledge & pocket & trap & vegetable \\
\hline food grown in gardens & & & & & & \\
\hline information which a person has & & & & & & \\
\hline middle number & & & & & & \\
\hline
\end{tabular}

Figure 1. Examples of the New Vocabulary Levels Test item

\subsection{Procedure}

The paper-and-pencil version of the NVLT was downloaded from Stuart Webb's and delivered to the participants in the first session of their English language course at university as part of the entry test. The students were informed that the test results would not affect their academic results, but would be used for research purposes to help teachers adjust their instructions to match learners' levels. Students were given as much time as they needed to complete the test.

\section{Results}

The Updated Vocabulary Levels Test scores of the participants were statistically analyzed with an SPSS for Microsoft Window Release 23.0 package. Table 1 presents the descriptive statistics (mean, min, max, and standard deviations) of the participants' scores on the Updated Vocabulary Levels Test. The first row of this table shows that the mean scores of these learners decreased according to the test levels, from $27.73(1,000$ word level) to 19.96 (2,000 word level), 13.11 (3,000 word level), 10.23 (4,000 word level) and then 7.95 (5,000 word level).

Table 1. Descriptive statistics of the Updated Vocabuary Levels Test $(\mathrm{N}=442)$

\begin{tabular}{ccccccc}
\hline Correct responses & 1,000 & 2,000 & 3,000 & 4,000 & 5,000 & Total \\
\hline Mean & 27.73 & 19.96 & 13.11 & 10.23 & 7.95 & 78.98 \\
Min & 20 & 0 & 0 & 0 & 0 & 26 \\
Max & 30 & 30 & 30 & 30 & 30 & 149 \\
$S D$ & 2.62 & 7.23 & 8.13 & 7.92 & 7.67 & 29.33 \\
Percentage of correct responses & $92.43 \%$ & $66.53 \%$ & $43.70 \%$ & $34.10 \%$ & $26.50 \%$ & $52.65 \%$ \\
\hline
\end{tabular}


As normality was confirmed, a one-way repeated measures ANOVA was conducted to compare learners' scores at the 1,000, 2,000, 3,000, 4,000, and 5,000-word levels. It was shown that there was statistically significant differences in the mean scores across five levels of the test, Wilks' Lambda $=.007, F(5,435)=13142.51, p<.0005$, $\eta^{2}=.99$. Post-hoc Bonferroni tests indicated that knowledge of words at higher frequency levels is significantly higher than knowledge of words at lower frequency levels. This finding indicates that the receptive vocabulary knowledge of the learners in this study followed the typical lexical profile. That is, they knew more words at higher frequency levels than words at lower frequency levels. To master a level of the Updated Vocabulary Levels Test, learners need to get at least 29 out of 30 correct answers per level (the 1,000, 2,000, and 3,000-word levels) and at least 24 out of 30 correct answer per level (the 4,000 and 5,000-word levels) (Webb et al., 2017). Applying these criteria, as a whole group, the learner participants had not mastered any levels of the Updated Vocabulary Levels Test. When the data of each student were examined, as shown in Figure 2, 90.05\% of the participants had not mastered the most frequent 2,000 words. Seriously, nearly half of the participants had not mastered the most frequent 1,000 words.

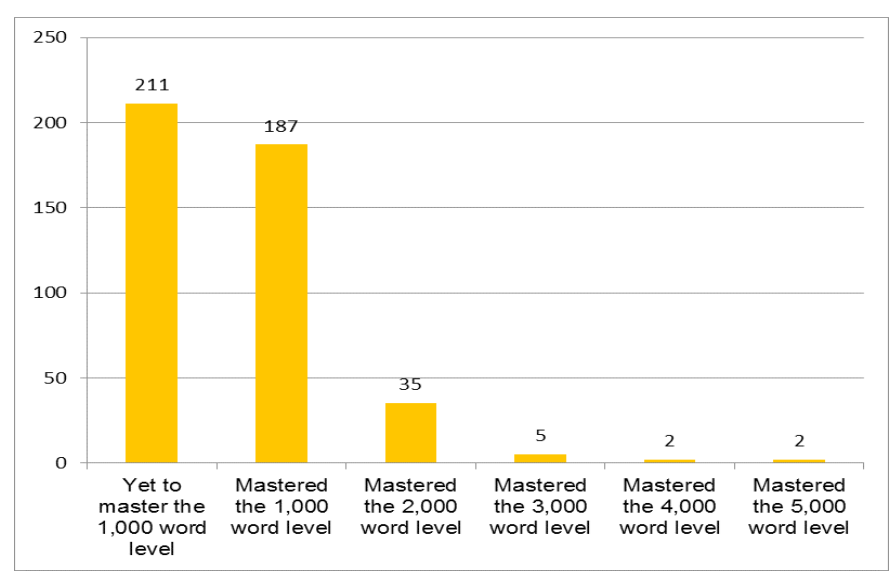

Figure 2. The number of students mastering each level of Webb, Sasao, and Balance's (2017) Updated Vocabulary Levels Test $(\mathrm{N}=442)$

\section{Discussion}

This study found that nearly half of the participants had not mastered the most frequent 1,000 words and more than $90 \%$ of the participants had not mastered the most frequent 2,000 words. It is important to note that this study only measured receptive knowledge of form and meaning relationship, a basic aspect of vocabulary knowledge (Schmitt, 2010; Webb \& Chang, 2012). Learning and using a word receptively is much easier than learning and using it productively (Nation, 2013). Thus, it is reasonable to expect that the participants' productive levels were even lower. The finding of this study is in line with previous studies conducted with other groups of Vietnamese EFL learners (Dang, 2020a; Nguyen \& Webb, 2017; Vu \& Nguyen, 2019). It is slightly different from Nguyen's (2020) findings. This different is probably because Nguyen did not report the scores of individual students, which makes it unclear about the proportion of learners mastering each level 
of the test. The finding of the present study is also consistent with the findings of previous studies with EFL learners in Denmark (Henriksen \& Danelund, 2015; Stæhr, 2008), Spain (Olmos, 2009), Indonesia (Nurweni \& Read, 1999), Taiwan (Webb \& Chang, 2012), and China (Matthews \& Cheng, 2015; Sun \& Dang, 2020).

There are two possible reasons for this alarming picture of the participants' vocabulary knowledge. The first reason may be the lack of input in EFL contexts. For second language vocabulary learning to happen, learners need to have a lot of exposure to the target language (Webb \& Nation, 2017). However, in EFL contexts such as in Vietnam, the input is very limited; classrooms appear to be the main environment for learners to get exposure to English. The lack of input would limit the chances of learning the most frequent words incidentally. The second reason may be the lack of a systematic focus on highfrequency words, especially the most frequent 1,000 words in EFL learning programs. Dang, Webb, and Coxhead (under review) found a strong correlation between the words perceived as being useful by Vietnamese EFL teachers and the words learned by Vietnamese EFL learners. This suggests teachers play a significant part in Vietnamese EFL learners' vocabulary development; that is, the words that teachers introduce to students are likely to be learned by learners. Dang and Webb's (2020) survey with experienced Vietnamese EFL teachers revealed that textbooks and tests are among the key factors affecting teachers' selection of words for instructions. Yet O'Loughlin's (2012) study of the vocabulary in the New English File textbooks, the course book which happened to be the textbook used by the participants in the present study, revealed that these textbooks contained a substantial number of low-frequency words while having an insufficient number of highfrequency words $(1,435$ out of the most frequent 2,000 word families). Similarly, in a thorough analysis of the reading texts in the new series of Grade 10, 11 and 12 English textbooks, Nguyen (2020) found that to reach $95 \%$ coverage of these texts, Vietnamese EFL learners would need a vocabulary size of 5,000 word families. Moreover, only $11.46 \%$ of the novel words presented in the textbooks were important for facilitating students' comprehension of the text content and only about $4.2 \%$ of the novel words occurred at least six times in the texts. Drawing on these findings, Nguyen (2020) suggested that highschool students may be overloaded with the large amount of new vocabulary presented in the textbooks and have few chances to consolidate and expand their vocabulary knowledge. $\mathrm{Vu}$ (2019) analyzed the lexical profile of high-school graduation exam papers and found that to reach $95 \%$ coverage, which indicated reasonable comprehension, knowledge of the most frequent 6,000 word families was needed. Considering the lexical demand of these tests with the vocabulary knowledge of high-school students reported in $\mathrm{Vu}$ and Nguyen (2019), Vu suggested that the high school graduation exam papers may be too demanding for students in terms of vocabulary.

Taken together, the findings of the current study echo the argument that institutional language learning programs should pay more attention to high-frequency words so that class time will be effectively used in helping learners master the words that are crucial for their language development (Dang \& Webb, 2016a, 2016b; Nation, 2016; Webb \& Chang, 2012). Although the most frequent 3,000 words should be the crucial vocabulary learning goals to Vietnamese EFL learners. Achieving this goal at once may be too demanding for many students. As shown in the present study and other studies with Vietnamese EFL learners (Dang, 2020a; Nguyen \& Webb, 2017; Vu \& Nguyen 2019), there are a considerable number of Vietnamese EFL learners having insufficient knowledge of the most frequent 1,000 words. It would be more sensible to draw beginner learners' 
attention to the most frequent words of English first. One possible option is Dang and Webb's (2016b) Essential Word List. This list was designed specifically for EFL beginners. It consisted of 800 strongest items selected from the GSL, BNC2000, BNC/COCA2000, and New-GSL. Learning only 800 items from this list, learners may be able to recognize up to $75 \%$ of the words in English language. This would create a solid foundation for further vocabulary learning.

To help learners learn high-frequency words, especially items from the Essential Word List, teachers should create plenty of opportunities for them to repeatedly encounter these words in different contexts both inside and outside classroom by following Nation's (2007) Four Strands principles: meaningfocused input, meaning-focused output, fluency development, and language-focused learning. Meaning-focused input activities help students to gain vocabulary knowledge by encountering the words repeatedly through listening and reading (e.g., extensive reading, extensive viewing) while meaning-focused output activities (e.g., writing emails, telling stories) are opportunities from them to learn vocabulary through writing and speaking. The importance of combining meaning-focused input and meaning-focused output is evident in Nguyen and Boer's (2018) study which found that the experimental group who watched a video, summarized the content of the video and watched it again picked up more words from the input than the control group who only watched the video twice without producing the output. Fluency development activities (e.g., speed reading, listening to easy stories, 10 minute writing) help students to learn through all four skills: listening, speaking, reading, and writing. Unlike meaning-focused input and output activities, fluency development activities do not aim to teach students new vocabulary but enable them to be able to use known items fluently. While meaning-focused input, meaning-focused output, and fluency development activities draw learners' attention to the meaning, language-focused learning activities (e.g., learning from word cards, checking dictionaries) draw their attention to the words themselves. Language-focused learning activities are important because the vocabulary gained from incidental learning (meaning-focused input and meaningfocused output activities) is much lower than the vocabulary gained from incidental learning (meaning-focused input and output activities) plus deliberate learning (language focused learning) (Sobul \& Schmitt, 2010). Additionally, not all aspects of vocabulary knowledge can be incidentally learned (Webb \& Nation, 2017). For example, Hoang and Boer (2016) found that even advanced level learners tend not to pay much attention to the multiword units in the input that they encountered, which highlights the significant role of explicit instruction in vocabulary learning and teaching.

As mentioned, there are a large number of words in English, which makes it impossible to teach all of these words within the limited class time. Therefore, it should be noted that while language-focused learning activities are important, they should not account for more than $25 \%$ of the class time (Nation, 2007). Also, these activities should focus on (a) helping learners learn and consolidate their knowledge of high-frequency words and (b) training vocabulary learning strategies so that they can keep expanding their vocabulary knowledge (Nation, 2013). Explicit instruction of the most frequent words ensures that learners will master the words that enable them to deal with a range of tasks in their future use of the language. Training vocabulary learning strategies such as dictionary checking and corpus-based analysis helps to develop learners' autonomy and expand their vocabulary knowledge (Bui, Boers, \& Coxhead, 2019). This study has several limitations which deserves attention from further research. It only measured the 
receptive vocabulary knowledge of Vietnamese non-English majored students in a university in the north of Vietnam. Studies that measure both the depth and breadth of vocabulary knowledge of learners in other contexts may provide further insights into Vietnamese EFL learners' vocabulary knowledge.

\section{Conclusion}

This study is among the very few attempts to measure Vietnamese EFL learners' receptive vocabulary knowledge. It revealed that despite many years of studying English, most of the learners had insufficient knowledge of highfrequency words, especially the most frequent 1,000 words. It then calls for more attention to high-frequency words, especially items from Dang and Webb's (2016b) Essential Word List.

\section{Acknowledgements}

I would like to thank the learner participants as well as the teachers who had introduced me to their students.

\section{References}

Alderson, J. C. (2007). Judging the frequency of English words. Applied Linguistics, 28(3), 383-409.

Brezina, V., \& Gablasova, D. (2015). Is there a core general vocabulary? Introducing the New General Service List. Applied Linguistics, 36(1), 1-22.

Bui, T., Boers, F., \& Coxhead, A. (2019). Extracting multiword expressions from texts with the aid of online resources. ITL - International Journal of Applied Linguistics. https://doi.org/10.1075/ itl.18033.bui

Dang, T. N. Y. (2020a). High-frequency words in academic spoken English: Corpora and learners. ELT Journal, 74(2), 146-155. https://doi.org/10.1093/elt/ccz057.

Dang, T. N. Y. (2020b). Corpus-based word lists in second language vocabulary research, learning, and teaching. In S. Webb (Eds.). The Routledge Handbook of Vocabulary Studies (pp. 288304). New York: Routledge.

Dang, T. N. Y., \& Webb, S. (2014). The lexical profile of academic spoken English. English for Specific Purposes, 33, 66-76.
Dang, T. N. Y., \& Webb, S. (2016a). Evaluating lists of high-frequency words. ITL - International Journal of Applied Linguistics, 167(2), 132-158.

Dang, T. N. Y., \& Webb, S. (2016b). Making an essential word list. In I. S. P. Nation (Ed.), Making and using word lists for language learning and testing (pp. 153-167). John Benjamins.

Dang, T. N. Y., \& Webb, S. (2020). Vocabulary instruction and the good language teachers. In C. Griffiths, Z. Tajeddin, \& A. Brown (Eds.), Lessons from good language teachers (pp. 203-218). Cambridge University Press.

Dang, T. N. Y., Webb, S., \& Coxhead, A. (2020.). Evaluating lists of high-frequency words: Teachers' and learners' perspectives. Language Teaching Research. https://doi. org/10.1177/1362168820911189

Dang, T. N. Y., Webb, S., \& Coxhead, A. (under review). The relationships between lexical coverage, learner knowledge, and teacher perceptions of the usefulness of high-frequency words.

Henriksen, B., \& Danelund, L. (2015). Studies of Danish L2 learners' vocabulary knowledge and the lexical richness of their written production in English. In P. Pietilä, K. Doró, \& R. Pipalová (Eds.), Lexical issues in L2 writing (pp. 1-27). Cambridge Scholars Publishing.

Hoang, H., \& Boers, F. (2016). Re-telling a story in a second language: How well do adult learners mine an input text for multiword expressions? Studies in Second Language Learning and Teaching, 6(3), 513-535.

Laufer, B., \& Ravenhorst-Kalovski, G. C. (2010). Lexical threshold revisited: Lexical text coverage, learners' vocabulary size and reading comprehension. Reading in a Foreign Language, 22(1), 15-30.

Matthews, J., \& Cheng, J. (2015). Recognition of high frequency words from speech as a predictor of L2 listening comprehension. System, 52, 1-13.

Nation, I. S. P. (2006). How large a vocabulary is needed for reading and listening? Canadian Modern Language Review, 63(1), 59-82.

Nation, I. S. P. (2007). The four strands. Innovation in Language Learning and Teaching, 1(1), 1-12.

Nation, I. S. P. (2012). The BNC/COCA word family lists. http://www.victoria.ac.nz/lals/about/staff/paulnation

Nation, I. S. P. (2013). Learning vocabulary in another language (2nd ed.). Cambridge University Press.

Nation, I. S. P. (2016). Making and using word lists for language learning and testing. John Benjamins.

Nation, I. S. P., \& Beglar, D. (2007). A vocabulary size test. The Language Teacher, 31(7), 9-13.

Nguyen, C. D. (2020). Lexical features of reading passages in English textbooks for Vietnamese high-school students: Do they foster both content 
and vocabulary knowledge? RELC. https://doi. org/10.1177/0033688219895045

Nguyen, C. D., \& Boers, F. (2018). The effect of content retelling on vocabulary uptake from a TED talk. TESOL Quarterly. https://doi.org/10.1002/tesq.441

Nguyen, L. T. C., \& Nation, P. (2011). A bilingual vocabulary size test of English for Vietnamese learners. RELC Journal, 42(1), 86-99.

Nguyen, T M H, \& Webb, S. (2017). Examining second language receptive knowledge of collocation and factors that affect learning. Language Teaching Research, 21(3), 298-230.

Nguyen, T. M. H, \& Webb, S. (2017). Examining second language receptive knowledge of collocation and factors that affect learning. Language Teaching Research, 31(3), 298-320.

Nurweni, A., \& Read, J. (1999). The English vocabulary knowledge of Indonesian university students. English for Specific Purposes, 18(2), 161-175.

Olmos, C. (2009). An assessment of the vocabulary knowledge of students in the final year of secondary education. Is their vocabulary extensive enough? International Journal of English Studies, Special Issue, 73-90.

O’Loughlin, R. (2012). Tuning into vocabulary frequency in coursebooks. RELC Journal, 43(2), 255-269.

Qian, D. D., \& Lin, L. H. F. (2020). The relationship between vocabulary knowledge and language proficiency. In S Webb (Ed.), The Routledge Handbook of Vocabulary Studies (pp. 66-80). Routledge.

Schmitt, N. (2000). Vocabulary in language teaching. Cambridge: Cambridge University Press.

Schmitt, N. (2010). Researching vocabulary: A vocabulary research manual. New York: Palgrave Macmillan.

Schmitt, N., Jiang, X., \& Grabe, W. (2011). The percentage of wnords known in a text and reading comprehension. The Modern Language Journal, 95(i), 26-43.

Schmitt, N., \& Schmitt, D. (2014). A reassessment of frequency and vocabulary size in L2 vocabulary teaching. Language Teaching, 47(4), 484-503.

Sonbul, S. and Schmitt, N. 2010. Direct teaching of vocabulary after reading: Is it worth the effort? ELT Journal, 64(3), 253-260.

Sun, Y. \& Dang, T. N. Y. (2020). Vocabulary in high-school EFL textbooks: Texts and learner knowledge. System, https://doi.org/10.1016/j. system.2020.102279

Stæhr, L. S. (2008). Vocabulary size and the skills of listening, reading and writin. The Language Learning Journal, 36(2), 139-152.

Tegge, F. (2017). The lexical coverage of popular songs in English language teaching. System, 67, 87-98.

The BNC/COCA2000 is available at Paul Nation's website: https://www.wgtn.ac.nz/lals/about/staff/ paul-nation.

Van Zeeland, H., \& Schmitt, N. (2013). Lexical coverage in L1 and L2 listening comprehension: The same or different from reading comprehension? Applied Linguistics, 34(4), 457-479.

Vu, D. V. (2019). A corpus-based lexical analysis of Vietnam's high-stakes English exames. The 20th English in Southeast Asia (ESEA) Conference, Singapore.

Vu, D. V., \& Nguyen, N. C. (2019). An assessment of vocabulary knowledge of Vietnamese EFL learners. The 20th English in Southeast Asia (ESEA) Conference, Singapore.

Webb, S. A., \& Chang, A. C.-S. (2012). Second language vocabulary growth. RELC Journal, 43(1), 113-126.

Webb, S, \& Rodgers, M. P. H. (2009). Vocabulary demands of television programs. Language Learning, 59(2), 335-366.

Webb, S., \& Chang, A. C.-S. (2012). Second language vocabulary growth. RELC Journal, 43(1), 113-126.

Webb, S., \& Nation, I. S. P. (2017). How vocabulary is learned. Oxford: Oxford University Press.

Webb, S., \& Rodgers, M. P. H. (2009). The lexical coverage of movies. Applied Linguistics, 30(3), 407-427.

Webb, S., Sasao, Y., \& Ballance, O. (2017). The updated Vocabulary Levels Test. ITL - International Journal of Applied Linguistics, 168(1), 33-69.

West, M. (1953). A general service list of English words. Longman, Green.

\section{Biodata}

Dang Thi Ngoc Yen is a Lecturer in Language Education at the University of Leeds, U.K. She obtained her PhD in Applied Linguistics from Victoria University of Wellington, New Zealand. Before joining the University of Leeds, she was a Lecturer at the University of Languages and International Studies, Vietnam National University, Hanoi. Her research interests include vocabulary studies and corpus linguistics. Her articles have been published in Language Learning, TESOL Quarterly, Language Teaching Research, System, English for Specific Purposes, Journal of English for Academic Purposes, ELT Journal, and ITL-International Journal of Applied Linguistics. 


\title{
KIẾN THỨC TIẾP NHẬN TÙ๋ VỰNG THÔNG DỤNG TRONG TIẾNG ANH CỦA SINH VIÊN VIÊTT NAM HỆ TIẾNG ANH KHÔNG CHUYÊN
}

\author{
Đặng Thị Ngọc Yến
}

Khoa Giáo dục, Truoòng Đại họ Leeds

Hillary Place, Woodhouse Lane, Leeds, U.K

Tóm tắt: Nghiên cứu sử dụng bài kiểm tra cấp độ từ vựng của Webb, Sasao và Balance (2017) để đo kiến thức tiếp nhận từ vựng của 422 sinh viên đại học hệ Tiếng Anh không chuyên trong một chương trình Tiếng Anh phổ thông ở Việt Nam. Kết quả cho thấy sau 10 năm học tiếng Anh, gần một nửa số sinh viên này vẫn chưa đạt được mức 1000 từ thông dụng trong tiếng Anh, và hơn $90 \%$ sinh viên chưa đạt được mức 2000 từ thông dụng. Nghiên cứu đề xuất việc giảng dạy tiếng Anh ở Việt Nam nên chú trọng hơn tới những từ thông dụng trong tiếng Anh.

Tù khóa: sinh viên Việt Nam học tiếng Anh như ngôn ngữ nước ngoài, kiến thức từ vựng, từ thông dụng, kiểm tra 